THURSDAY, DECEMBER 9, 1875

\section{SCIENTIFIC AGRICULTURE}

GARMING is a complex business. It embraces a greater variety of objects and interests than any other industrial pursuit. Its two great ends are the production of crops and the production of animals. It is among the oldest occupations of man. Its history has been very peculiar. In our own day the system of farming pursued by the great bulk of occupiers of land is far behind the state of agricultural knowledge ; and many of the practices of the most enlightened of our farmers are based on empirical data. Various agencies have becn proposed for promoting agricultural progress. For the instruction of the mass we must look chiefly to the diffusion of agricultural knowledge through the medium of ordinary schools and colleges, as was pointed out some time ago in NATURE. For further progress in the acquisition of accurate knowledge we must look chiefly to expeximental investigations.

In Germany they have had in operation for some years a number of experimental stations which are partly supported by the State, and which are said to work satisfactorily. France and other European countries are following the example of Germany. Recently the subject has been ventilated in Great Britain. It has been forced on our attertion by a number of persons who are seemingly desirous of giving to the farmer every aid which science can suggest.

British experience of experinental stations is very limited. We bappen to have one at Rothamstead in England, which was described in NATURE last year, and which we owe to the enterprise of Mr. John Bennett Lawes, F.R.S., the great manure manufacturer. He has for upwards of thirty years used a part of his estate for experimental purposes. He has published the results in a vast number of papers. The whole is the work of the man himself. He has had no aid from the Government or any agricultural society, and no advice from any committee or public body. He has obtained a larger body of facts in relation to manures and cropping, and the feeding of animals, than all the agricultural societies in thie empire put together. It is manifestly desirabie to dweil on his labours and to contrast them with the more public system projected tsewhere.

To Mr. Lawes' experiments I hope to be able to devote another paper before long. For the present I shall merely draw attention to the circumstances on which, in my judgment, the success which has attended his labours has depended. Mr. Lawes has not had an unqualified success, especially in drawing inferences from his facts. But his writings afford ample evidence of great earnestness of purpose. His manly, outspoken language shows that he loves truth for its own sake. He has had ample resources; and he has had the motive of selfinterest, as well as love of knowledge, to stimulate him in his investigations.

Here, then, we have a private individual who, unaided by the State, or by any scientific body, has made a greater number of useful experiments than all the experimental farms of European Governments put together. Had the British Government established experimental stations Vul. xilu.-No. $3 \mathrm{~s}$ before $\mathrm{Mr}$. Lawes commenced, would he have established his? And if not, would British agriculture have derived more useful results from the governmental stations than from his?

These are questions which cannot be answered by direct evidence. We possess, however, data which enable us to throw light upon them. It is notorious that the agriculture of Scotland has made great progress within the past one hundred years. The improvement of agriculture within that period has been greater in parts of Scotland than in any part of England. Yet the demand for means of effecting further progress is greater among the most advanced farmers of Scotland than among the most advanced English farmers. There is no man in Scotland who has come forward, or offers to come forward, to do for Scotland what Mr. Lawes has done and offers to do for England. The friends of agricultural progress in Scotland are endeavouring to effect, by co-operation, what the private enterprise of Mr. Lawes is doing for England. The subject has been discussed in English agricultural classes, more or less, for several years. The discussion has during the past few weeks assumed a practical shape to which it may be useful to refer. A member of the Council of the Royal Agricultural Society of England, Mr. Randell, desires to "prove, by a series of experiments, under every variety of soil and circumstances, how far the accuracy of the estimated value of manures obtained by the consumption of different articles of food as given by Mr. Lawes, is confirmed by practical results." Mr. Randell was supported by the Earl of Lichfield and Lord Vernon, and the matter was referred to the Chemical Committee of the Society. Mr. Randell has so far confined himself to one point, which has been suggested to his mind by the passing of the Agricultural Holdings Act of 1875 . If one or more stations be established, the experiments would of course cover a wider field. The question arises at once, how are the experiments to be directed? Could Mr. Lawes be induced to act as Director-General? $\mathrm{He}$ could be assisted by a representative council. In due time the best man to succeed him would appear.

In Scotland the movenent has of late been agitated with energy and intelligence. The Royal Agricultural Society of that country, better known as the Highland Society, has a large surplus fund, and contains among its members the leading gentry, many enlightened professional men, and a great array of intelligent farmers. It has been suggested that some of this fund should be applied to the maintenance of experimental stations. Several reports and suggestions have been made. It is said that a sum of $700 l$. a year, and no more, is available for the purpose.

One of the reports goes on to state that "considering the advantages which had already been derived from chemistry in its application to agriculture, it was expedient to reorganise a chemical department under the cognisance of the Society, for the purpose of conducting investigations on all subjects relating to agriculture ; and that in connection therewith a series of carefully conducted experiments in the open ground be instituted." The directors found that the Society had at its disposal, for the purpose of the chemical department and field experiments, a sum of $700 l$., which they recommended should be set aside for a period of seven years. In 
carrying out these recommendations they sugges ed that the 700\%. should be expended as follows:- "Chemist's salary, 300l. ; agricultural inspector's salary, I 50l." \&c.

The report must render it plain to anyone who has had experience in experimental work of the kind contemplated that this part of the recommendation is based on imperfect knowledge. What evidence is there in the history of the Society, or elsewhere, which goes to show that the best man to initiate and conduct investigations on all sub. jects relating to agriculture should be a professional chemist? Such a man should have a good general knowledge of all the sciences relating to agriculture. He should be well known as a man of broad views and great grasp of mind. He should, moreover, be thoroughly conversant with the details of modern agriculture. He should have given evidence of being imbued with an ardent desire to elicit truth, as well as of his taste and fitness for conducting experiments. We submit that a really good chemist, possessing all these qualifications, can seldom be found. If he exists in Scotland, let him by all means be made director of the proposed station or stations; not, however, because he is a chemist, but because he is the best man. There are many chemists who would doubtless be glad to accept such an appointment, and who would be as unfit for it as for the direction of the Channel fleet. It seems incredible that any body of thoughtful men would propose to trust the initiation and direction of experiments on crops and animals to a man who would not necessarily know anything of the habits of either.

A most peculiar part of the report of the committee to which the Highland Society referred the consideration of this question is the remuneration ( $150 l$. a year) they propose for an agricultural inspector. If the views of the committee were acted on, the bonta fide value of the experiments would depend on this officer. He should be an accomplished agriculturist. He should possess great intelligence, the highest personal character, and the most rigid love of truth, as well as the sternest sense of duty. He would be expected to initiate experiments from which results of national importance would flow. And this is the man for whom the munificent sum of $150 \%$ a year is proposed! If a man like Mr. Lawes were to undertake the duty, he would accept no remuneration. In this case 5 50l. a year may be a fair sum to cover travelling and other expenses. But if a competent man is to be employed who cannot afford to work gratuitously, a salary equal to that of the average of intelligent professional men must be offered. This part of the Report has been already denounced in strong and emphatic language ; and we understand it has been opposed by leading members of the Society who value science and appreciate the work to be done. The action of the committee has been openly exposed by Mr. David Milne Home, an ardent advocate of the application of science to agriculture, and by Mr. John Wilson, of Eddington Mains, a truly enlightened farmer. These gentlemen contend that the directing head or body should have the power to call in the professional aid of the best chemist or chemists, and such other experts as may be needed. This view is based on common sense. If they prevail in the councils of the Society, we may expect to see ere long in Scotland agricultural stations which in all human probability will give a new stimulus to agricultural progress. If they fail, and the work is entrusted to men who are not in every way equal to it, we may get an annual crop of worthless or misleading results, like those which have formed so large a portion of our agricultural literature.

While the Royal Agricultural Society of Scotland is discussing these matters, a local Agricultural Association formed in Aberdeenshire has actually fixed sites for five stations, at which experiments will be conducted for three years. The Marquis of Huntley is president of the Society, and Mr. Barclay M.P., is among the active members. A sum exceeding $\mathrm{r}, 000 \mathrm{l}$. has been already subscribed. For the present the experiments will be confined to the determination of the best states in which to apply phosphates and nitrogen. Each plot is to be I-I I th part of an acre. It is to be regretted that potash and one or two other constituents of plants will not be tried. In some respects the scheme devised by the Association corresponds with that which I have carried out at Glasnevin for several years, and the results of which I have not, owing to pressure of other work, been able to publish. In the Glasnevin experimental ground the several crops are crossed by the manures; and thus we bring out the results in a striking way, and guard against inequalities in the soil. We also raised three consecutive grain crops without manure before commencing the experiments.

THOMAS BALDWIN

\section{THE NEW GEOMETRY \\ Syllabus of Plane Geometry (corresponding to Euclid, Books i.-vi.) Prepared by the Association for the Improvemert of Geometrical Teaching. (London: Macmillan, I875.)}

THE readers of NATURE are so well acquainted with 1 the genesis and growth of the Association whose syllabus has recently been given to the public, that we are relieved from all necessity of explaining what objects it has in view. The main result of its five years of labour is this Syllabus, and we shall here briefly exhibit some of its chief features. It is a double syllabus, being a syllabus of geometrical constructions and a syllabus of plane geometry. The former is very brief, and contains such constructions as can be made with the ruler and compasses only. This subject of constructive geometry has been tried in many schools of late and has been found generally to answer the end in view. Boys thus obtain some idea of the objects of pure geometry and of what is involved in the postulates of the science. The more important syllabus is prefaced by a Logical Introductionnot that the Association wishes "to imply by this that the study of geometry ought to be preceded by a study of the logical independence of associated theorems." The opinion of the compilers is "that at first all the steps by which any theorem is demonstrated should be carefully gone through by the student, rather than that its truth should be inferred from the logical rules here laid down. At the same time they strongly recommend an early application of general logical principles." The President, in one of his addresses, states that the object of this introduction is "to guide the teacher immediately, and the student ultimately." It contains certain general axioms (as the whole is greater than its part), and taking as its typical theorem, if $A$ is $R$ ? 